PENELITIAN | RESEARCH

\title{
Pengetahuan Demam Berdarah Dengue pada Siswa di Berbagai Level Pendidikan Wilayah Pangandaran
}

\author{
Dengue Knowledge of Students Among Education Levels in Pangandaran Region \\ Joni Hendri11, Heni Prasetyowati1, Dewi Nur Hodijah¹, Rizal Pratama Sulaeman ${ }^{1}$ \\ ${ }^{1}$ Loka Litbangkes Pangandaran, Jl Raya Pangandaran KM 3 Babakan Pangandaran
}

\begin{abstract}
School is one of the potential sites for transmission of Dengue Haemorrhagic Fever (DHF). The level of education is thought to be a major knowledge determinant about the disease and its transmission, as well as attitudes and practices for controlling dengue fever. This study aims to describe dengue knowledge in a student at various levels of education to prevent dengue transmission. Three hundred students participated in this study, as many as 98 students were male, while 202 students were female. The average elementary school student is 10.7 years old, junior high school students are 14 years old, and senior high school students are 16.5 years old. Based on the interview results it can be seen the percentage of students with favorable knowledge about DHF for elementary school level 49.5\%; Junior High 38.89\%; Senior High 37.50\%, while knowledge of DHF vector control at the elementary level is 3.4\%; Junior High 3.7\% and Senior High 2.5\%. The percentage of students taking vector control measures for the elementary level is $0.49 \%$, Junior High $9.26 \%$, and high school 5\%. Age and sex do not show a relationship with knowledge and actions towards DHF. Knowledge about DHF and the eradication of DHF vectors and the eradication of DHF vectors in students at various levels of education in the Pangandaran area is still low. The socialization of 3M Plus must be carried out thoroughly and continuously in schools to increase the knowledge and participation of students in controlling DHF.
\end{abstract}

\section{Keywords: Knowledge, Dengue, School, Pangandaran}

\begin{abstract}
Abstrak. Sekolah merupakan salah satu tempat potensial dalam penyebaran dan penularan penyakit Demam Berdarah Dengue (DBD). Level pendidikan diduga merupakan penentu utama pengetahuan tentang penyakit dan penularannya, serta sikap dan praktik untuk pengendalian demam berdarah. Tujuan dari penelitian kami adalah untuk menggambarkan pengetahuan yang dimiliki oleh siswa sekolah pada berbagai level pendidikan dalam kaitannya dengan upaya yang dilakukan untuk mencegah penularan penyakit DBD. Total sampel dalam penelitian ini adalah 300 siswa yang diambil berdasarkan teknik perhitungan sampel dari populasi siswa pada masing-masing tingkatan pendidikan. Pengumpulan data dilakukan dengan melakukan wawancara menggunakan kuesioner yang terstruktur. Siswa yang diwawancara merupakan siswa yang ditunjuk oleh sekolah sebagai anggota Unit Kesehatan Sekolah (UKS). Dari 300 siswa yang ikut serta dalam penelitian ini sebanyak 98 siswa berjenis kelamin laki-laki, sedangkan 202 siswa berjenis kelamin perempuan. Usia rata-rata siswa SD berkisar 10,7 tahun, siswa SLTP adalah 14 tahun sedangkan usia rata-rata anak SLTA adalah 16,5 tahun. Berdasarkan hasil wawancara terlihat persentase siswa dengan pengetahuan baik tentang DBD untuk level SD 49,5\%; SLTP 38,89\%; SLTA $37,50 \%$ sedangkan pengetahuan tentang pengendalian vektor DBD pada level SD 3,4\%; SLTP 3,7\% dan SLTA 2,5\%. Persentase siswa yang melakukan tindakan pengendalian vektor untuk level SD 0,49\%; SLTP 9,26\%; dan SLTA 5\%. Usia dan jenis kelamin tidak menunjukkan hubungan dengan pengetahuan dan tindakan terhadap DBD. Pengetahuan tentang DBD dan pemberantasan vektor DBD serta tindakan pemberantasan vektor DBD pada siswa di berbagai level pendidikan di wilayah Pangandaran masih rendah. Sosialisasi PSN 3M Plus perlu dilakukan di sekolah untuk meningkatkan pengetahuan dan peran serta siswa dalam pengendalian DBD.
\end{abstract}

Kata Kunci: Pengetahuan, Demam Berdarah Dengue, Sekolah, Pangandaran 


\section{PENDAHULUAN}

Demam Berdarah Dengue (DBD) merupakan penyakit tular vektor yang mendapat perhatian khusus dari pemerintah Indonesia. Hal ini dikarenakan, jumlah kasus DBD di Indonesia sangat tinggi, bahkan WHO mengkategorikan Indonesia sebagai negara endemis tinggi DBD. Hampir seluruh kabupaten/kota di Indonesia telah terjangkit penyakit DBD. Jumlah kabupaten tertinggi yang terjangkit DBD terjadi pada tahun 2016. Tercatat 463 dari 514 atau sekitar $90.08 \%$ kabupaten/kota di Indonesia melaporkan kejadian DBD. Pada tahun 2016, angka kejadian DBD sebesar 70 per 100.000 penduduk menurun pada tahun 2017 sebesar 26,10 dan tahun 2018 sebesar 24,75 per 100.000 penduduk. ${ }^{1,2}$

Demam Berdarah Dengue disebabkan oleh virus dengue dari famili Flaviviridae. Terdapat empat serotipe virus dengue yang beredar di Indonesia yaitu DEN-1, DEN-2, DEN-3, dan DEN-4. Spesies nyamuk Aedes aegypti betina adalah vektor utama untuk penularan infeksi dengue. Spesies ini aktif pada pagi sampai sore hari, periode puncaknya adalah pagi hari dan sore menjelang senja. Nyamuk yang tidak terinfeksi menjadi terinfeksi ketika menggigit orang yang terinfeksi virus dengue. Manusia yang terinfeksi virus dengue baik yang menunjukkan gejala atau tidak bergejala adalah sumber penularan utama virus ini. ${ }^{3}$

Penyakit DBD dapat menyerang semua kelompok umur. Namun beberapa hasil penelitian menunjukan bahwa anak-anak lebih rentan tertular DBD. Salah satu alasan yang dikemukakan adalah karena faktor imunitas (kekebalan) dan status gizi pada anak. ${ }^{4}$ Hasil penelitian di Kelompok berisiko terjangkit DBD pada umur $<12$ tahun berisiko 19,06 kali terkena DBD dibandingkan kelompok umur $\geq 12$ tahun. ${ }^{5}$ Penelitian di Blitar menunjukkan bahwa kejadian DBD paling tinggi terjadi pada anak-anak berusia 5-14 tahun. 6 Berdasarkan risiko keparahannya, kasus perdarahan lebih banyak terjadi pada remaja dan orang dewasa tetapi kebocoran plasma lebih banyak terjadi pada anak-anak pra sekolah dan usia sekolah. ${ }^{7}$

Salah satu tempat potensial dalam penyebaran dan penularan penyakit DBD pada anak-anak adalah sekolah. Sebagian besar anakanak menghabiskan separuh harinya di sekolah. Di sisi lain nyamuk Aedes sebagai vektor DBD, aktif menggigit pada pagi sampai sore hari bersama dengan aktivitas anak sekolah dan warga sekolah lainnya. Banyaknya tempat perkembangbiakan potensial vektor DBD yang dapat ditemukan di sekolah. Dan penemuan jentik dengan kepadatan yang tinggi dilaporkan di beberapa daerah seperti Banjarbaru, ${ }^{8}$ Medan Tuntungan, ${ }^{9}$ Lampung Selatan, ${ }^{10}$ Semarang 11 dan Kota Sukabumi. ${ }^{12}$ Hasil penelitian tersebut menunjukkan potensi penularan DBD di sekolah cukup tinggi.

Kelompok anak sekolah merupakan bagian kelompok masyarakat yang dapat berperan strategis, mengingat jumlahnya sangat banyak sekitar 20\% dari jumlah penduduk Indonesia adalah anak sekolah SD, SLTP dan SLTA. Anak sekolah tersebar di semua wilayah Indonesia, baik daerah perkotaan maupun pedesaan. Dalam upaya pencegahan penularan DBD, anak sekolah dapat berperan dalam upaya Pemberantasan Sarang Nyamuk (PSN) baik di sekolah maupu di rumahnya. Sebuah penelitian yang dilakukan di Duren Sawit menyimpulkan bahwa terdapat hubungan yang bermakna antara pengurasan kontainer dengan keberadaan jentik Aedes sp. di sekolah yang diteliti. ${ }^{13}$ Dalam upaya tersebut, pemerintah telah meluncurkan program dalam memberdayakan anak sekolah sebagai juru pemantau jentik (jumantik) sebagai upaya PSN di sekolah. Tujuan program ini adalah sebagai upaya untuk menerapkan PHBS sedini mungkin, dan mencegah kejadian DBD di sekolah. ${ }^{14}$

Dalam hal pemberantasan DBD, seseorang memerlukan pengetahuan dasar tentang bahaya penyakit DBD, bagaimana cara menghindari penularannya dan bagaimana cara melakukan pengendalian vektor DBD. Trisnaniyanti (2015) dalam Wulandari et al. menyebutkan bahwa ada hubungan yang bermakna antara pengetahuan tentang pencegahan DBD dengan persepsi kader PSN DBD dalam pencegahan DBD serta adanya hubungan bermakna antara persepsi kader PSN DBD dengan aktivitas pencegahan DBD. ${ }^{15}$ Terkait dengan hal tersebut maka dalam upaya mencegah penularan DBD di sekolah, pengetahuan DBD perlu di sosialisasikan kepada para siswa agar mereka mampu berperan serta.

Semakin tinggi pengetahuan siswa maka semakin tinggi motivasinya dalam melaksanakan tindakan PSN.16 Pengetahuan berpengaruh terhadap tindakan. Peningkatan pengetahuan masyarakat tentang DBD berdampak dalam peningkatan upaya pengendalian vektor DBD. Berbagai penelitian menunjukkan adanya korelasi antara tingkat pendidikan dan pengetahuan dengan perilaku pengendalian vektor. Semakin tinggi tingkat pengetahuan seseorang tentang pentingnya upaya pengendalian vektor maka upaya untuk mengendalikan vektor DBD juga semakin besar. $17,18,19$

Tingkat pendidikan diduga menjadi penentu utama pengetahuan tentang penyakit dan 
penularannya, serta sikap dan praktik, terutama yang melibatkan integrasi upaya masyarakat untuk pengendalian demam berdarah. Kabupaten Pangandaran merupakan salah satu kabupaten endemis DBD di Provinsi Jawa Barat yang telah melakukan berbagai upaya pemberantasan DBD. Keterlibatan siswa di sekolah baik Sekolah Dasar, Sekolah Menengah Tingkat Pertama maupun Sekolah Menengah Tingkat Atas diperlukan untuk mengantisipasi penularan di lingkungan sekolah. Pemilihan Kecamatan Pangandaran sebagai lokasi penelitian didasarkan bahwa Kecamatan Pangandaran memiliki jumlah anak sekolah tertinggi di Kabupaten Pangandaran. Tujuan dari studi ini adalah untuk menggambarkan pengetahuan yang dimiliki oleh anak-anak sekolah pada berbagai level pendidikan dalam kaitannya dengan upaya yang dilakukan untuk mencegah penularan penyakit DBD di wilayah Kecamatan Pangandaran.

\section{METODOLOGI}

Studi ini merupakan analisis lanjut dari hasil penelitian "Evaluasi implementasi Usaha Kesehatan Sekolah dalam Pengendalian Vektor Demam Berdarah Dengue di Kecamatan Pangandaran Kabupaten Pangandaran.". Pada penelitian ini dilakukan studi cross-sectional pada siswa sekolah dasar (SD), sekolah menengah tingkat pertama (SLTP) dan sekolah menengah tingkat atas (SLTA) di Kecamatan Pangandaran. Total populasi adalah 11.842 siswa. Dengan perhitungan rumus Slovin diperoleh sampel sebanyak 300 siswa yang kemudian dilakukan perhitungan sampel proporsi untuk masingmasing level. Sebanyak 300 siswa berpartisipasi dalam penelitian ini terdiri dari 206 siswa sekolah dasar, 54 siswa sekolah menengah pertama dan 40 siswa sekolah menengah atas. Penarikan sampel menggunakan metode rancangan acak sederhana. Pengumpulan data dilakukan dengan melakukan wawancara menggunakan kuesioner terstruktur. Siswa yang diwawancarai merupakan anggota Unit Kesehatan Sekolah (UKS) yang terpilih secara acak.
Dalam studi ini dilakukan analisis lanjut terhadap beberapa pertanyaan yaitu identitas responden, pengetahuan tentang demam berdarah (pernah mendengar informasi DBD, pengetahuan penularan demam berdarah, pengetahuan bahaya demam berdarah), pengetahuan tentang pencegahan demam berdarah (pernah mendengar 3M Plus, mampu menyebutkan 3M Plus, mengetahui tempat keberadaan jentik, menyebutkan tempat keberadaan jentik), sumber pengetahuan demam berdarah, serta upaya yang dilakukan untuk mencegah penularan DBD (pernah melakukan pemantauan jentik, rutin melakukan pemantauan jentik serta di mana biasanya menemukan jentik). Setiap jawaban yang benar diberi bobot 1 dan setiap jawaban salah atau tidak tahu diberi bobot 0 . Beberapa pertanyaan yang terkait dengan jawaban setelahnya diberi bobot 2 jika jawaban pertanyaan setelahnya juga benar. Setiap jawaban siswa dikategorikan "Baik" jika hasil akumulasi jawaban $\geq 75 \%$ dari nilai akumulasi jawaban maksimal dan kategori "Kurang Baik" jika hasil akumulasi jawaban $<75 \%$ dari nilai akumulasi jawaban maksimal. Data dianalisis secara deskriptif untuk masing-masing level pendidikan dengan menunjukkan pesentase pembobotan pengetahuan siswa pada masing-masing level. Uji hubungan bivariat juga dilakukan dalam studi ini untuk mengetahui hubungan antara jenis kelamin dan umur terhadap pengetahuan.

\section{HASIL}

Total terdapat 300 siswa yang berperan serta dalam penelitian terdiri dari 206 siswa SD, 54 siswa SLTP dan 40 siswa SLTA. Dari 300 siswa yang ikut serta dalam penelitian ini sebanyak 98 siswa berjenis kelamin laki-laki, sedangkan 202 siswa berjenis kelamin perempuan. Usia rata-rata siswa SD berkisar 10,7 tahun, siswa SLTP 14 tahun, sedangkan usia rata-rata anak SMA adalah 16,5 tahun. Berdasarkan hasil wawancara sebanyak 96\% siswa dalam berbagai level pendidikan pernah mendengar tentang DBD, namun hanya $50 \%$ siswa yang tahu bahwa

Tabel 1. Presentase Pengetahuan DBD Siswa Semua Level Pendidikan di Kecamatan Pangandaran

\begin{tabular}{lcr}
\hline \multicolumn{1}{c}{ Pengetahuan tentang DBD } & Tahun & Tidak \\
\hline Pernah mendengar informasi DBD & $96 \%$ & $4 \%$ \\
Penyakit DBD dapat menular & $50 \%$ & $50 \%$ \\
Bagaimana penularan DBD & $53 \%$ & $47 \%$ \\
Penyakit DBD menyebabkan kematian & $88 \%$ & $12 \%$ \\
Pernah mendengar 3M plus & $15 \%$ & $85 \%$ \\
Mengetahui tempat keberadaan jentik & $95 \%$ & $5 \%$ \\
\hline
\end{tabular}


DBD dapat menular. Dari 50\% siswa yang tahu bahwa DBD menular, hanya 53\% siswa yang tahu bahwa DBD ditularkan oleh nyamuk. Sebanyak 88\% siswa tahu bahwa DBD dapat menyebabkan kematian namun, $15 \%$ siswa yang menyatakan pernah mendengar 3M plus. Sebanyak 95\% siswa menyatakan tahu tempat keberadaan jentik. Masih ada siswa yang menyatakan bahwa selokan merupakan tempat perkembangbiakan vektor DBD. Presentase pengetahuan DBD siswa semua level pendidikan di Kecamatan Pangandaran terlihat pada Tabel 1.

Berdasarkan hasil pembobotan terhadap pengetahuan siswa di masing-masing level pendidikan terlihat bahwa pengetahuan DBD dan pengetahuan terhadap pengendalian vektor DBD pada semua tingkat pendidikan didominasi kategori kurang baik. Pembobotan terhadap pengetahuan DBD didasarkan pada jawaban responden tentang pernah mendengar DBD, mengetahui apakah DBD menular, mengetahui cara penularan DBD serta mengetahui bahaya DBD. Pembobotan terhadap pengetahuan pengendalian vektor didasarkan pada jawaban responden yang menyatakan pernah mendengar $3 \mathrm{M}$ plus, mampu menyebutkan dengan benar $3 \mathrm{M}$ plus, mengetahui tempat keberadaan jentik dan mampu menyebutkan dengan benar tempattempat keberadaan jentik. Hasil pembobotan terhadap tindakan pengendalian vektor juga menunjukkan hasil yang sama yaitu sebagian besar dalam kategori kurang baik pada semua level pendidikan. Pembobotan terhadap tindakan pengendalian vektor didasarkan pada jawaban responden yang menyatakan melakukan kegiatan untuk mencegah gigitan nyamuk baik secara rutin baik dilingkungan sekolah maupun rumah. Hasil pembobotan terhadap pengetahuan DBD, pengetahuan pengendalian vektor dan tindakan pengendalian vektor tersaji pada Tabel 2-4.

Sumber informasi tentang demam berdarah diperoleh responden pada tingkatan SD dan SLTA didominasi keluarga sedangkan pada SLTP sumber informasi dari media elektronik mendominasi. Secara keseluruhan keluarga, sekolah, dan media elektronik mendominasi sebagai sumber informasi DBD yang di terima oleh siswa di berbagai tingkat pendidikan. Gambaran sumber informasi yang diterima oleh siswa pada berbagai tingkat pendidikan tersaji pada grafik 1.
Tabel 2. Hasil Pembobotan Pengetahuan tentang DBD di Berbagai Level Pendidikan

\begin{tabular}{|c|c|c|}
\hline STRATA & $\mathbf{N}$ & $\%$ \\
\hline $\mathrm{SD} / \mathrm{MI}$ & 206 & 100 \\
\hline Baik & 102 & 49,51 \\
\hline Kurang Baik & 104 & 50,49 \\
\hline SMP/MTS & 54 & 100 \\
\hline Baik & 21 & 38,89 \\
\hline Kurang Baik & 33 & 61,11 \\
\hline SMA/SMK/MA & 40 & 100 \\
\hline Baik & 15 & 37,50 \\
\hline Kurang Baik & 25 & 62,50 \\
\hline
\end{tabular}

Tabel 3. Hasil Pembobotan Pengetahuan tentang Pengendalian Vektor di Berbagai Level Pendidikan

\begin{tabular}{crr}
\hline \multicolumn{1}{c}{ STRATA } & N & \% \\
\hline SD/MI & 206 & 100 \\
Baik & 7 & 3,40 \\
Kurang Baik & 199 & 96,60 \\
\hline SMP/MTS & 54 & 100 \\
Baik & 2 & 3,70 \\
Kurang Baik & 52 & 96,30 \\
\hline SMA/SMK/MA & 40 & 100 \\
Baik & 1 & 2,50 \\
Kurang Baik & 39 & 97,50 \\
\hline
\end{tabular}

Tabel 4. Hasil Pembobotan Tindakan Pengendalian Vektor di Berbagai Level Pendidikan

\begin{tabular}{|c|c|c|}
\hline STRATA & $\mathbf{N}$ & $\%$ \\
\hline $\mathrm{SD} / \mathrm{MI}$ & 206 & 100 \\
\hline Baik & 1 & 0,49 \\
\hline Kurang Baik & 205 & 99,51 \\
\hline SMP/MTS & 54 & 100 \\
\hline Baik & 5 & 9,26 \\
\hline Kurang Baik & 49 & 90,74 \\
\hline SMA/SMK/MA & 40 & 100 \\
\hline Baik & 2 & 5,00 \\
\hline Kurang Baik & 38 & 95,00 \\
\hline
\end{tabular}




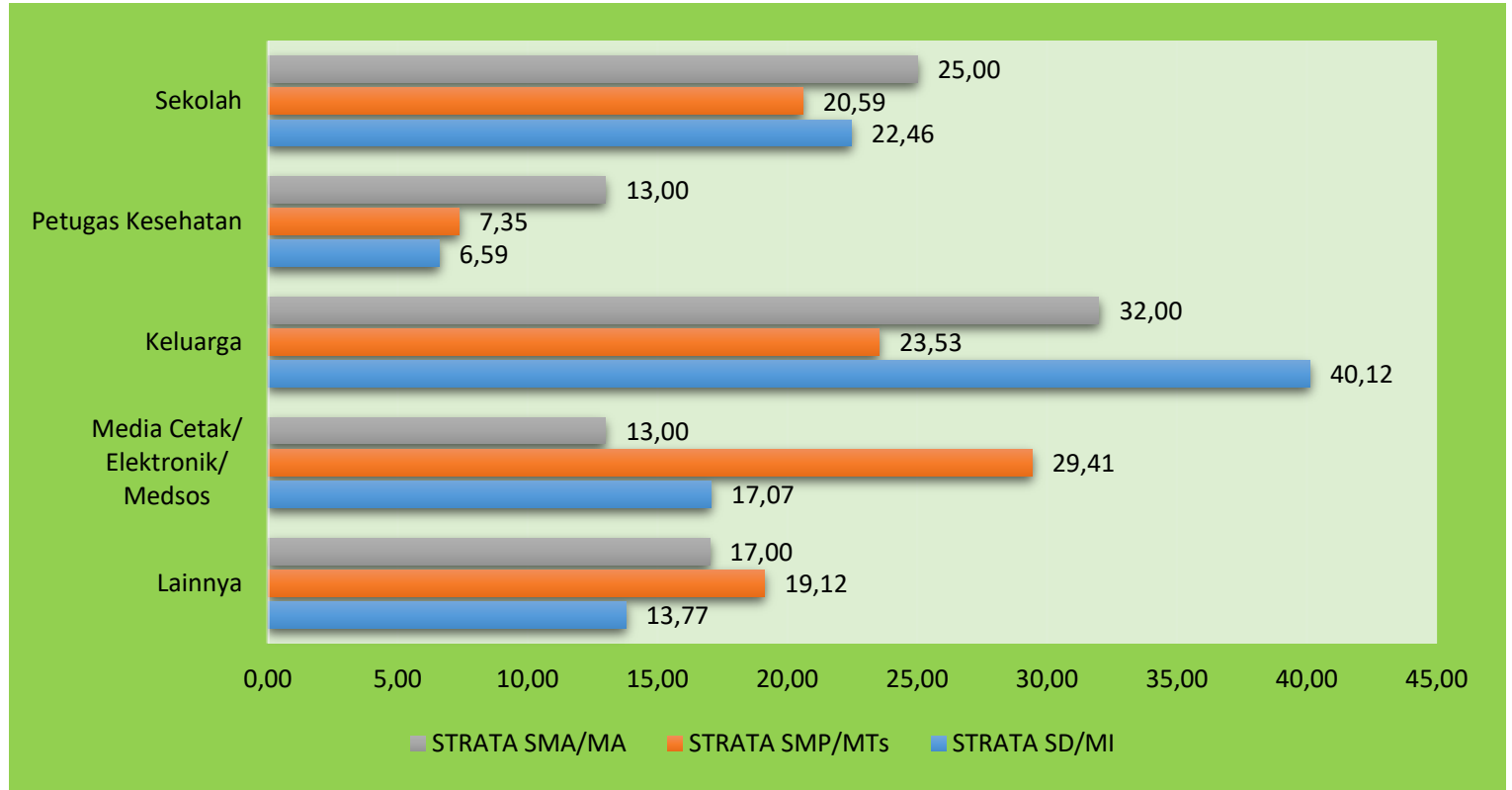

Gambar 1. Sumber informasi DBD yang diterima siswa pada berbagai level pendidikan

\section{PEMBAHASAN}

Hasil penelitian ini menunjukkan sebagian besar siswa pada semua level memiliki pengetahuan yang kurang baik tentang demam berdarah. Mayoritas siswa pernah mendengar penyakit demam berdarah, namun hanya sedikit yang mengetahui bahwa demam berdarah menular melalui gigitan nyamuk. Hal ini menunjukkan bahwa masih banyak siswa yang belum mengetahui seluk-beluk penyakit DBD. Hasil beberapa penelitian mengenai pengetahuan DBD terhadap siswa di Indonesia memperlihatkan kurangnya pengetahuan siswa terhadap DBD dapat dikarenakan kurangnya edukasi tentang penyakit DBD kepada siswa. Kurangnya pengetahuan ini berdampak pada rendahnya peran serta siswa dalam upaya pemberantasan penyakit DBD. Program pencegahan dan pemberantasan DBD yang dicanangkan oleh pemerintah dalam upaya menurunkan angka kejadian DBD berhubungan erat dengan peran serta masyarakat dalam perencanaan dan pelaksanaan aktivitas-aktivitas program. Pengetahuan masyarakat masih kurang karena tidak memiliki akses langsung terhadap informasi dan pengetahuan mengenai program, yang merupakan prakondisi bagi peran serta warga dalam suatu program. Hal ini disebabkan penyuluhan, yang merupakan saluran penyampaian informasi dari para pelaksana program di lapangan kepada warga masyarakat, belum berjalan dengan baik; karena adanya berbagai kendala pada pelaksana program di lapangan. Masyarakat sudah melakukan caracara untuk mencegah dan memberantas penyakit DBD. Cara yang mereka lakukan berhubungan erat dengan sistem pengetahuan mereka mengenai penyakit ini. Bervariasi dan kurang akuratnya pengetahuan warga masyarakat setempat mengenai penyakit ini mengakibatkan mereka melakukan cara-cara pencegahan dan pemberantasan penyakit DBD yang kurang akurat pula. ${ }^{20,21,22}$

Hasil penelitian serupa juga di temukan di daerah lain. Penelitian yang dilakukan di Nepal menyimpulkan bahwa hanya $12 \%$ dari responden memiliki pengetahuan yang baik tentang demam berdarah, ${ }^{23}$ sementara sebuah penelitian yang dilakukan di Jamaika menyimpulkan bahwa 87\% dari responden memiliki pengetahuan yang buruk tentang demam berdarah. ${ }^{24}$ Sebuah studi di Laos melaporkan bahwa 93\% dari responden percaya bahwa mereka tidak memiliki pengetahuan yang cukup tentang demam berdarah. ${ }^{25}$ Dari hasil penelitian di Kota Bandung mendapatkan hasil bahwa yang memiliki pengetahuan baik sebanyak $9,1 \%$, yang memiliki pengetahuan cukup sebanyak $72,7 \%$ dan yang memiliki pengetahuan kurang sebanyak 18,2\%.26

Dari segi pengetahuan pencegahan DBD terlihat bahwa siswa yang pernah mendengar dan menyebutkan kepanjangan dari $3 \mathrm{M}$ plus hanya sebesar 15\%. Pengendalian DBD telah diatur dalam Keputusan Menteri Kesehatan Nomor 581/MENKES/SK/VII/1992 tentang Pemberantasan Penyakit Demam Berdarah dan Keputusan Menteri Kesehatan nomor 92 tahun 1994 tentang perubahan atas lampiran Keputusan Menteri Kesehatan Nomor 581/MENKES/SK/1992, dengan menitikberatkan pada upaya pencegahan dengan gerakan pemberantasan sarang nyamuk (PSN). Program 
3M plus merupakan salah satu kegiatan PSN. Program 3M ini telah diintensifkan sejak tahun 1992 dan pada tahun 2000 dikembangkan menjadi 3M Plus, yaitu dengan cara menggunakan larvasida, memelihara ikan, dan mencegah gigitan nyamuk. ${ }^{27}$ Namun, masih banyak masyarakat yang belum mengetahui tentang program 3M Plus ini.

Pemberantasan Sarang Nyamuk dapat dilakukan secara efektif jika mengetahui habitat nyamuk vektor DBD dan siklus hidup nyamuk. Terdapat beberapa siswa yang mampu menyebutkan tempat perkembangbiakan vektor DBD, namun sebagian besar masih menyebutkan bahwa vektor DBD hidup di selokan. Pengetahuan habitat vektor DBD dan bagaimana cara melakukan pemberantasannya perlu disosialisasikan terhadap masyarakat. Menurut Khun dan Manderson, pengetahuan habitat berperan penting dalam partisipasi masyarakat untuk pengendalian vektor. ${ }^{28}$ Masyarakat dengan pengetahuan baik tentang habitat vektor DBD, bagaimana siklus hidupnya dan bagaimana cara pemberantasanya akan lebih mengetahui tindakan apa harus dilakukan untuk mencegah DBD. Penelitian di Kota Bandung menunjukkan pengetahuan mengenai PSN Plus dapat meningkatkan 1,4 kali kebiasaan responden untuk melakukan tindakan menguras dan menutup kontainer air. ${ }^{29}$

Peningkatan pengetahuan DBD kepada siswa dapat dilakukan dengan cara memberikan edukasi kesehatan baik secara formal maupun informal. Edukasi kesehatan ini dapat dilakukan oleh pihak sekolah sendiri maupun petugas kesehatan yang bertanggung jawab terhadap UKS. Edukasi kesehatan secara rutin dapat diberikan kepada siswa untuk memberi pengetahuan vektor dan upaya pengendaliannya. ${ }^{28}$ Proses pembelajaran yang melibatkan interaksi guru sebagai pendidik dan siswa sebagai peserta didik. Siswa sebagai subjek diharapkan mampu menerapkan hidup sehat dalam kehidupan sehari-hari. Perubahan perilaku sehat melalui pendidikan kesehatan bukan sekadar mentransfer ilmu pengetahuan dan sikap dari guru, tetapi bagaimana siswa dapat berperilaku dengan mewujudkan keseimbangan antara lingkungan, perilaku, dan manusia. Pendidikan kesehatan di sekolah dapat diwujudkan melalui UKS. ${ }^{30}$ Pendekatan siswa belajar melalui metode seperti audio visual dapat digunakan untuk meningkatkan pengetahuan pengendalian vektor pada siswa SD/ MI untuk mencegah DBD di sekolah. ${ }^{31}$

Perbedaan level pendidikan dalam penelitian ini ternyata tidak menunjukkan adanya perbedaan tingkat pengetahuan dan tindakan dalam pengendalian dan pemberantasan DBD di sekolah. Level SLTA yang merupakan level tertinggi seharusnya memiliki pengetahuan dan tindakan yang lebih baik dari level dibawahnya, namun hasil penelitian menunjukkan level SLTA juga memiliki pengetahuan dan tindakan yang kurang baik, bahkan secara persentase lebih rendah dari level dibawahnya. Hasil ini bertentangan dengan hasil dari Putri pada 2017 yang menyatakan bahwa terdapat hubungan yang signifikan antara variabel tingkat pendidikan dengan perilaku pencegahan ${ }^{32}$

Pada studi ini juga dilakukan analisis hubungan jenis kelamin dan usia terhadap pengetahuan DBD. Hasilnya menunjukkan bahwa usia dan jenis kelamin tidak berhubungan dengan pengetahuan DBD yang dimiliki siswa. Hasil ini bertolak belakang dengan hasil penelitian di Jamaika yang menunjukkan bahwa terlepas dari tingkat pendidikan, usia berhubungan dengan pengetahuan tentang penyakit dan mekanisme penularannya. ${ }^{24}$ Selain itu, penelitian di Colombia menyebutkan bahwa sikap positif dan praktik dalam pencegahan penularan juga bertambah seiring bertambahnya usia. Perempuan memiliki kecenderungan pengetahuan yang lebih baik tentang penyakit dan penularan. Hal ini mungkin disebabkan karena perempuan lebih peka dalam mengenali penyakit dan mencegah penularannya. ${ }^{33}$

Keterbatasan penelitian ini adalah sulitnya mengukur jawaban tentang pengetahuan dan tindakan pengendalian vektor yang di sebutkan oleh responden dengan realita yang sebenarnya. Mengingat jawaban responden terutama pada siswa sekolah dasar kadang tidak konsisten. Namun, hasil penelitian ini memberikan gambaran kurangnya pengetahuan dan tindakan siswa-siswa terkait pencegahan penyakit DBD di wilayah Pangandaran. Dalam demam berdarah, serta untuk penyakit tropis lainnya, pendidikan adalah pilar dasar untuk pengendalian, pencegahan, dan promosi terpadu. Penentu ini harus dipertimbangkan dalam pengembangan kebijakan publik yang mungkin dapat mengurangi penyakit secara stabil dan dampaknya pada daerah endemis. Secara khusus, hasil penelitian ini merekomendasikan sosialisasi atau penyuluhan dengan mempertimbangkan kelompok usia. Intervensi yang ditargetkan ini dapat lebih efisien dan memiliki dampak yang lebih besar pada sikap dan praktik pencegahan.

Secara keseluruhan hasil penelitian menunjukkan bahwa keluarga, sekolah dan media elektronik menjadi sumber informasi tentang DBD paling banyak bagi para siswa. Peran 
ketiganya seharusnya dapat digunakan sebagai media sosialisasi. Hasil penelitian di Kota Labuhan Batu menunjukkan bahwa Orang tua dan sumber informasi berpengaruh terhadap pengetahuan lingkungan siswa. ${ }^{33}$ Media elektronik seperti televisi, radio maupun internet menjadi sumber informasi yang banyak di akses oleh para siswa. Media elektronik ini memiliki berbagai keunggulan, diantaranya dapat dilihat dan bergerak serta terdengar sehingga lebih mengena dan diterima oleh para siswa. Studi yang dilakukan di Laos, Malaysia dan Thailand menunjukkan bahwa radio dan televisi adalah sumber informasi terpenting dan sebagai sumber informasi paling umum tentang demam berdarah. ${ }^{34-37}$

Ketiga sumber informasi tersebut dapat digunakan sebagai sarana untuk meningkatkan pengetahuan siswa tentang DBD. Dalam menumbuhkan perilaku pengendalian vektor DBD melalui promosi kesehatan di sekolah diperlukan langkah-langkah strategis, yaitu: a) informasi yang disampaikan adalah hal yang paling relevan dan sangat penting sehingga mengandung konsekuensi logis pada bagaimana seharusnya berbagai informasi diseleksi, serta disampaikan kepada khalayak, b) strategi pendidikan harus dirancang sedemikian rupa sehingga tumbuh kesadaran dan praktik mengendalikan vektor di kalangan murid, c) orang tua, guru dan tenaga kesehatan perlu ditingkatkan perannya sebagai sumber informasi pengendalian demam berdarah. ${ }^{32}$

\section{KESIMPULAN}

Berdasarkan hasil sudi ini dapat disimpulkan bahwa pengetahuan tentang DBD dan upaya pemberantasan vektor DBD serta tindakan pemberantasan vektor DBD pada siswa di berbagai tingkatan pendidikan di wilayah Pangandaran masih rendah. Usia dan Jenis kelamin tidak berhubungan dengan pengetahuan dan tindakan terhadap DBD. Sosialisasi PSN 3M Plus harus dilakukan secara komprehensif dan berkesinambungan. Komprehensifitas dan kesinambungan program dapat dicapai apabila dilakukan promosi kesehatan di di sekolah.

\section{UCAPAN TERIMA KASIH}

Penulis menyampaikan terima kasih kepada Badan Litbangkes RI dan Loka Litbangkes Pangandaran yang mendanai penelitian dan studi ini. Ucapan terima kasih juga disampaikan untuk Heni Prasetyowati atas konsep dan bimbingan studi ini, serta para peneliti dan kontributor.

\section{KONTRIBUSI PENULIS}

Peran penulis pada studi ini yaitu Joni Hendri dan Heni Prasetyowati sebagai kontributor utama, Dewi Nur Hodijah dan Rizal Pratama Sulaeman sebagai kontributor anggota. Kontribusi penulis dapat dilihat pada rincian berikut :

$\begin{array}{lll}\begin{array}{l}\text { Conceptualization } \\ \text { Data Curation }\end{array} & : \mathrm{HP} \\ \begin{array}{l}\text { Formal Analysis } \\ \text { Visualization }\end{array} & \mathrm{JH} \\ \begin{array}{l}\text { Writing-Original } \\ \text { Draft Preparation }\end{array} & : & \mathrm{JH}, \mathrm{HP}, \mathrm{DNH}, \mathrm{RPS}\end{array}$

Writing-Review \& : JH, HP, DNH, RPS Editing

\section{DAFTAR RUJUKAN}

1. Kemenkes RI. Profil Kesehatan Indonesia Tahun 2017. Jakarta: Kementerian Kesehatan Republik Indonesia; 2018.

2. Kemenkes RI. Profil Kesehatan Indonesia Tahun 2018. Jakarta: Kementerian Kesehatan RI; 2019.

3. Javed N, Ghazanfar H, Naseem S. Knowledge of Dengue Among Students Exposed to Various Awareness Campaigns in Model Schools of Islamabad: A Cross-Sectional Study. Cureus. 2018;

4. Hasian DU. Hubungan Status Gizi Dengan Derajat Infeksi Virus Dengue Pada Anak. Universitas Syiah Kuala Aceh; 2016.

5. Faldy R, Kaunang WPJ, Pandelaki AJ. Pemetaan kasus demam berdarah dengue di Kabupaten Minahasa Utara. J Kedokt Komunitas dan Trop. 2015;3(2):73-81.

6. Suryani ET. Gambaran Kasus Demam Berdarah Dengue Di Kota Blitar Tahun 20152017. J Berk Epidemiol. 2018;6(3):260-7.

7. Pone SM, Hökerberg YHM, Brasil P, Nicolai CCDA, Ferrari R, De Oliveira RDVC. Sociodemographic inequalities in the clinical characteristics of dengue haemorrhagic fever in the city of Rio de Janeiro, Brazil, 2007-2008. Epidemiol Infect. 2018;146(3):359-66.

8. Alim L, Heriyani F, Istiana. Tingkat kepadatan jentik nyamuk Aedes aegypti 
pada tempat penampungan air controllable sites dan disposable sites di Sekolah Dasar Kecamatan Banjar Baru Utara. Berk Kedokt. 2017;13(1):7-14.

9. Pane AF. Analisis Keberadaan Jentik Nyamuk Aedes Aegypti dan Faktor Lingkungan pada Sekolah Dasar di Kecamatan Medan Tuntungan Tahun 2017. Universitas Sumatra Utara; 2018.

10. Sutarto, Talkah. Studi Indeks Larva DBD Pada Sekolah Dasar Se- Kecamatan Kalianda 2015. JK Unila. 2013;1(3).

11. W.H. Cahyati?, D.M. Sukendra, Yunita D.P. Santik. Penurunan Container Index (CI) Melalui Penerapan Ovitrap Di Sekolah Dasar Kota Semarang. Unnes J Public Heal. 2016;5(4).

12. Nurhodijah D, Prasetyowati H, Marina R. Tempat perkembangbiakan Aedes Spp. sebagai penular virus dengue pada berbagai tempat di Kota Sukabumi. J Ekol Kesehat. 2015;14(1):1-7.

13. Ramadhan BI, Achmadi UF. Keberadaan Jentik Aedes aegypti dan Aedes albopictus Berdasarkan Karakteristik Kontainer di Sekolah Dasar, Keluharan Duren Sawit, Jakarta Timur, Tahun 2018. J Nasion al Keseh atan Lin gkungan Glob. 2020;1(1).

14. Kemenkes RI. Petunjuk Teknis Jumantik-PSN Anak Di Sekolah. Jakarta: Kementerian Kesehatan RI; 2014.

15. Wulandari W, Istiningtyas A, Oktariani M. Hubungan motivasi kader pemeberantasan sarang nyamuk dengan upaya pencegahan demam berdarah dengeu di wilayah kerja Puskesmas Gemolong. 2016; Available from: http://digilib.stikeskusumahusada.ac.id/file s/disk1/34/01-gdl-wiwikwulan-1696-1artikel-i.pdf

16. Afrian N, Widayati D, Setyorini D. Pengembangan Model Motivasi Jumanior (Juru Pemantau Jentik Junior) Dalam Perilaku PSN (Pemberantasan Sarang Nyamuk) Aedes Aegypti Berbasis Integrasi Model Lawrance Green Dan Mc. Clelleand. J Ilm Kesehat. 2016;9(2):129-37.

17. Bestari RS, Siahaan PP. Hubungan Tingkat Pengetahuan Dan Perilaku Mahasiswa Tentang Pemberantasan Sarang Nyamuk (PSN) Demem Berdarah Dengue (DBD) Terhadap Keberadaan Jentik Aedes Aegypti. Biomedika. 2018;10(1).

18. Sartiwi W, Apriyeni E, Sari IK. Hubungan Pengetahuan dan Sikap dengan Perilaku
Keluarga tentang Pemberantasan Sarang Nyamuk Deman Berdarah Dengue di Korong Sarang Gagak Wilayah Kerja Puskesmas Enam Lingkung Kabupaten Padang Pariaman. J Kesehat Med Saintika. 2018;9(2).

19. Farhandika M, Wardani Rengganis Dyah Wulan Sumekar, Setiawan G. Hubungan Pengetahuan dan Status Sosial Ekonomi Terhadap Upaya Pencegahan Demam Berdarah Dengue (DBD) di Desa Pajaresuk Kecamatan Pringsewu Kabupaten Pringsewu. Majority. 2018;7(3).

20. Awaluddin. Korelasi Pengetahuan Dan Sikap Keluarga Terhadap Tindakan pencegahan Demam Berdarah Dengue. J Endur. 2017;2(3):263-9.

21. Susanty N, Tahlil T, Ismail N. Pengetahuan Sikap Dan Tindakan Ibu-Ibu Rumah Tangga Pada Saat Pra Bencana Wabah Penyakit Demam Berdarah Dengue Di Kota Banda Aceh. J Ilmu Kebencanaan Pascasarj Univ Syiah Kuala. 2017;4(3).

22. Zulaikhah, Thomas S, Yusuf I. Pengaruh Penyuluhan terhadap Kepadatan Aedes aegypti dalam Pencegahan Demam Berdarah. Kes Mas J Fak Kesehat Masy. 2018;12(1)

23. Dhimal M, Aryal KK, Dhimal ML, Gautam I, Singh SP, Bhusal CL, et al. Knowledge, attitude and practice regarding dengue fever among the healthy population of highland and lowland communities in Central Nepal. PLoS One. 2014;9(7)

24. Alobuia WM, Missikpode C, Aung M, Jolly PE. Knowledge, Attitude, and Practices Regarding Vector-borne Diseases in Western Jamaica. Ann Glob Heal. 2015;81(5):654-63.

25. Mayxay M, Cui W, Thammavong S, Khensakhou K, Vongxay V, Inthasoum L, et al. Dengue in peri-urban Pak-Ngum district, Vientiane capital of Laos: A community survey on knowledge, attitudes and practices. BMC Public Health. 2013;13(1).

26. Restalia G. Gambaran Pengetahuan Siswa Kelas V SD Mengenai Pencegahan DBD (Demam Berdarah Dengue) Dengan Gerakan 3M (Menguras, Menutup, Dan Mengubur Barang Yang Dapat Menampung Air) Di SDN Jalah Anyar Kota Bandung. Universitas Pendidikan Indonesia.; 2015.

27. Ramadhani F, Yudhastuti R, Widati S Pelaksanaan PSN 3M Plus untuk Pencegahan Demam Berdarah Dengue (Studi Kasus Masyarakat Desa Kamal). Gorontalo J Public 
Heal. 2019;2(2):139.

28. Khun S, Manderson L. Community and school-based health education for dengue control in rural Cambodia: A process evaluation. PLoS Negl Trop Dis. 2007;1(3).

29. Fuadzy H. Hubungan Pengetahuan Dengan Tindakan Dalam Pemberantasan Sarang Nyamuk (PSN) di Kota Bandung. Bul Penelit Sist Kesehat. 2019;22(1):27-33.

30. Yanto. Peran Usaha Kesehatan Sekolah (UKS) Dalam Meningkatkan Kesehatan Anak SDN 002 Lumbis Ogong Kabupaten Nunukan. eJournal Sosiatri-Sosiologi. 2017;5(3):7690.

31. Pratiwi AS, Mutiara $\mathrm{H}$, Fakhruddin $\mathrm{H}$. Perbedaan Peningkatan Pengetahuan tentang Demam Berdarah Dengue antara Metode Ceramah dan Video Animasi Pada Murid Kelas V dan VI SD Negeri 12 Metro Pusat. Majority. 2018;7(3).

32. Putri R, Naftassa Z. Hubungan Tingkat Pendidikan dan Pengetahuan Masyarakat dengan Perilaku Pencegahan Demam Berdarah dengue di Desa Kemiri,Kecamatan Jayakerta, Karawang tahun 2016. jurnal.unimus.ac.id. 2017;1(4).

33. Silalahi E, Syarifuddin, Sudibyo M. Faktorfaktor yang Mempengaruhi Terhadap Pengetahuan Tentang Lingkungan pada
Siswa Tingkat SMP/MTS N dan SMA/MAN Adiwiyata di Kota Labuhanbatu. J Pendidik Biol. 2016;5(3).

34. Rao G, Minhat H, Hayati K. Predictors of practices related to dengue fever prevention among international students in Universiti Putra Malaysia, Serdang [Internet]. Vol. 3, International Journal of Public Health and Clinical Sciences. 2016. Available from: http://publichealthmy.org /ejournal/ojs2/index.php/ijphcs/article/vi ewFile/329/284

35. Sayavong C, Chompikul J, Wongsawass S, Rattanapan C. Knowledge, attitudes and preventive behaviors related to dengue vector breeding control measures among adults in communities of Vientiane, capital of the Lao PDR. J Infect Public Health. 2015;8(5):466-73.

36. Boonchutima $\mathrm{S}$, Kachentawa $\mathrm{K}$ Limpavithayakul M, Prachansri A. Longitudinal study of Thai people media exposure, knowledge, and behavior on dengue fever prevention and control. J Infect Public Health. 2017;10(6):836-41.

37. Krianto T. Tidak Semua Anak Sekolah Mengerti Demam Berdarah. Makara, Kesehatan [Internet]. 2009;13, No.2,:99103. Available from: core.ac.uk/display/ 112240578 
Pengetahuan Demam Berdarah Dengue pada Siswa di Berbagai Level Pendidikan Wilayah Pangandaran ...(Joni Hendri, et al) 